\title{
Heritage of borderland and population development trends in the cross-border area of Albania-Montenegro
}

In this paper, we are trying to analyze some of the most important issues, which are clearly evident in the cross-border relations between Albania and Montenegro, such as population developments and related social themes in this particular sociogeographical cross-border space. The object of our research is particularly focused on such issues concerning the general overview of the cross-border population of Shkodra and Malësia e Madhe Municipalities in the part of the cross-border area of Albania and the population of Kraja, Ulcinj, Plava, Gucia and Tuzi in the cross-border area of Montenegro, the number of population, the transformations expressed in different periods, their features and characteristics, their reasons and factors that have influenced on their evolution during these periods of population development, their future tendency, themes and social problems accompanying their progress on both sides of the border, etc.

Keywords: cross-border area, population development, trends, Albania-Montenegro.

\section{Introduction}

The cross-border areas have currently occupied much interdisciplinary research by various scholars as they are part of objects in a wide range of scientific disciplines. Diversity in scientific research, it turns out, goes with a variety of themes that these cross-border areas are featured, by their historical development context, their significant part in the geopolitical development framework, transitions, changes and economic evolutions, elements of the population and its social characteristics, environmental issues as well, etc. This multilayered optics has also promoted regional and international co-operation in Europe and beyond, not only in terms of the social function of power (local and central governments in the separate cross-border countries), but also in the respective cross-border scientific institutions and beyond (such as many universities or other scientific research centers in these diverse cross-border regions). 
There are many examples of this cross-border dimension in terms of several research, studies and co-operations. In this framework, we can identify more than one diverse research activities and case studies between Poland and Ukraine, Austria and Slovenia, Italy and Croatia, Sweden and Denmark, Finland and Estonia, etc. Albania and Montenegro have taken significant steps to boost the research and cross-border cooperation. In particular, it is estimated that the scientific study relationships and rapports between Shkodra University and Podgorica University, as well as many other scientific research centers on both sides of the border between Albania and Montenegro are highly effective.

There has been much scientific research studies by scholars which include a wide range of topics about the contribution of Geography in different issues (Axhemi 2002, 2005). Numerous geographers through their participation in various EU-funded projects and other local and international bodies, through their scientific publications in the science bulletins of respective Universities, science events such as scientific conferences or periodical meetings, as a result of many social events held in Shkodra, Velipoja, Podgorica, Ulcinj, Kraja, Plava, Gucia, Kelmendi, etc., have tried to provide geographical analysis on different issues of geographical optics. It is worth mentioning topics related to the crossborder economic development, tourism and its role in the economic development between the two countries, the evolution of the sociogeographical space, the relations between various social groups on both sides of the border, the evolution of social space and social rela-tions, issues of migration and population movements on both sides of the border, as well as environmental issues, etc.

\section{Population and its development in the cross-border area of Albania-Montenegro}

It is a very interesting topic to be analyzed from the geographical point of view. This seems to be closely related to the topics covered in the scientific scope of the geographical approach of the population. We epmphasize the fact that, certain conditions and factors have influenced and played an important role in the evolution of the cross-border population, some of which are: the history of the relationship between them, the different stages in which they have gone through, their corresponding features, the transformations appeared in different periods, population movements and migration diversity, migration destinations and its diverse effects, as well as other policies on the population on both sides of the border, etc. 
The Albanian population in the cross-border area with Montenegro is part of the population in the municipalities of Shkodra and Malësia e Madhe. The population and settlement of these territories has been present at earlier times and also influenced by the important events that have been developed during the important moments in the history of our nation. Therefore, it should be noted in the context of the role that different factors have played in their population, in particular the role of the historical factor is quite remarkable. We estimate that the administrative relevance of the administrative units that we are analyzing during the various periods has been closely related to the respective administrative divisions of these periods during the different political systems. Their distribution extends across the nation border with Montenegro, in which the most evident administrative units are those of Ana e Malit, Velipoja, Dajçi, Shirokë-Zogaj in the Municipality of Shkodra and administrative units of Kastrati and Kelmendi in the municipality of Malësia e Madhe (Axhemi 2005).

The key features of this population indicate the transformations in different periods of their development, which are influenced by the main natural-geographical, political, historical, economic and social factors. Regarding to these factors' impact, the Albanian population in this cross-border area with Montenegro is very dynamic and accompanied by important developments with a variety of its indicators. Most significant indicators refer to the number of population according to their administrative divisions, their evolution, natural growth, their respective indicators, migration processes, and settlements, etc.

Regarding to the natural-geographical factors, the potentials and resources of these administrative units should be evaluated by and large. The role of the landform, climate, hydrography and land is very important and favourable in terms of population establishment and their developments during the various periods in these territories. From our point of view, these natural-geographical factors have had their influence on these territories both in terms of their individualisation and in cooperation with each other. This is clearly expressed in the natural resources and important potentials of these territories in a variety of ways. We also estimate that, these natural and important resources are present nearly in every place or play a significant part in the distribution and establishment of this population along the cross-border area with Montenegro. We can mention places of Velipoja, Muriqani, a part of the mountain of Ana e Malit, and Kelmendi, etc.

There is a recognizable, naturally formed feature such as landform's diversity, including landscape of plains (Ana e Malit, Dajçi, Velipoja, administrative units of Bajza and Hoti), of hills (Shirokë-Zogaj area, Taraboshi Mountain, Pentari in Dajç,) and of mountains that is represented by Kelmendi's administrative unit 
(mostly Vermoshi) which has been a very positive opportunity for the development and establishment of the population, also in building a structure of diverse functions of social places, housing, production, exchange and entertainment. Due to this favourable landform, other geographical areas such as Ana e Malit and Dajçi have been harvested and cultivated many agricultural crops. We also estimate the fact that, these geographical areas of agricultural output have been very essential elements not only to meet the needs of this population, but also to supply the population of Shkodra and beyond. There are many examples to illustrate in this regard.

The diverse climate and key hydrographic potentials, with the presence of the Buna and Cem rivers, the Shkodra Lake, etc., have enabled the economic and tourist development of these administrative units, as well as the stimulation of many agricultural and livestock sectors. Taking into account that this is feasible due to the diversity and productivity of the soils of these administrative units by planting and cultivating different types of agricultural crops like (vegetables, varieties of fruit, potatoes, beans, various industrial-medicinal plants, etc.) as well as the use of the rich forestland in the administrative unit of Kelmendi.

On the other hand, the economic development of these administrative units with important impacts on agriculture and livestock, in the wood industry, have been a key factor in the establishment and development of the population. Agriculture, livestock and forestry have been predominant in the economic structure of these territories during various periods of development. Intensive agricultural development, included in the system of functioning of former agricultural cooperatives has been Oblika (including Ana e Malit), Dajçi, Kopliku, including Kastrati and Kelmendi. It was with great interest the development of livestock where not only Ana e Malit and Dajçi are highlighted, but also the mountainous areas of Kelmendi. Regarding to forestry, Kelmendi forest resources have had a very important development, where many of these territories serve as an important source of raw materials supply to the wood industry, which has been welldeveloped in the period before 1990s in Albania. This state of economic structure of these territories enabled the employment of local populations in these priority sectors such as agriculture, livestock and forestry (Axhemi 2005).

The economic development of these territories took on a new direction after the 1990 s, especially in terms of the tourist economy's development. Most natural potentials of the relief, climate and hydrography in many of these territories have been turned into important oases of tourist developments. In particular, Vermoshi and many administrative units of Kelmendi are making the most of the alpine tourist potentials, absorbing ever-increasing flows of foreign and Albanian tourism 
year by year. Also other administrative units such as Zogaj, Velipoja, Muriqani, etc., closely related to the presence of the Buna River and the Adriatic Sea, have influenced in the growth and development of tourist activities by expanding the respective social, residential, production and entertainment places. Tamara's administrative unit is developing an important perspective after the opening of a new border crossing point with Montenegro, whereas the tourist interest to exploit the alpine landform and resources of the area, in particular the Cem River is constantly growing. All these elements have had a significant impact on the development of the population of these cross-border territories with Montenegro.

Regarding to other features of the population in these administrative units (Ana e Malit, Velipoja, Dajçi, Shirokë-Zogaj, Kastrati and Kelmendi), we estimate that the number of people and its evolution have undergone changes in two different periods. The most evident changes are shown during the time up to the beginning of the 1990s and during the transition period. We made an analysis of this crossborder area and carefully proved the evidence that since the beginning of the 1990s, the main evident feature of these administrative units was a closed population. The natural growth of the population is closely related to the rates of birth (natality) and death (mortality), it appears as a key feature in the population's progress for a multi-year period until the beginning of transition. It is hard to find other features, although you may see sporadic internal migration toward urban areas, mainly for the purpose of official move of employees. The main destinations of population's establishment migrating from these administrative units were mostly from Shkodra and Kopliku, known as the main urban centers at that time.

Table 1. Population in the cross-border area with Montenegro

\begin{tabular}{|l|c|c|c|}
\hline \multirow{2}{*}{ Administrative unit } & \multicolumn{3}{|c|}{ Year } \\
\cline { 2 - 4 } & 2003 & 2011 & 2016 \\
\hline Ana e Malit & 6,400 & 3,858 & 3,860 \\
\hline Velipoja & 7,923 & 5,198 & 5,034 \\
\hline Dajçi & 8,517 & 4,014 & 3,887 \\
\hline Shirokë-Zogaj & 1,554 & 1,784 & 1,900 \\
\hline Kastrati & 9,337 & 6,883 & 11,400 \\
\hline Kelmendi & 6,594 & 3,056 & 6,850 \\
\hline
\end{tabular}

Source: S. Axhemi (2005) and own studies.

The same situation has continued after 1990s, whereas the migration movements of the population started to other administrative units of Albania. International and external migrations were relatively more intensive toward the main 
destinations of Italy, Greece and the USA (especially residents of Kelmendi, influenced by the historical tradition). We estimate that a new type of migration will appear with the passing of the years, especially for the population of Ana e Malit, mainly Muriqani and Oblikë, as well as Bajza and Hoti area in the administrative unit of Kastrati, i.e. temporary or transitory migration. The people of these areas move throughout the day toward Montenegro, mainly in the areas of Tuzi and Ulcinj, for many seasonal jobs related to different activities in agriculture, livestock and the construction and tourism sectors (Haxhibrahimi 1994).

The image of changes would be slightly different, if we had analyzed other censuses recorded to the previous periods in all these administrative units, but as we stated earlier in our paper, we found it especially difficult due to many administrative divisions before the ' $90 \mathrm{~s}$.

\section{Features of the development of the Albanian population in Montenegro}

The Albanian population in Montenegro is generally located geographically in the cross-border area with Albania. Absolutely, it goes without saying that, its establishment, on-going population and the evolution and development of its sociogeographical space is highly related to the historical factor.

This Albanian population has been featured in years for being persistent, resistant and well-determined to preserve and further developing the Albanian tradition and customs in the former Yugoslavia. The evolution of this population is mainly attributed to the role of the natural movement of the population, influenced by the birth and death ratios and further on the migration movement of the population. Based on the literature we used for this case study, we agreed that after all, migration has undergone changes in different periods due to a variety of reasons, migration patterns and destinations. This diversity is shown in the cases of both internal and external migration (Ushaku 1991).

Regarding to the general number of the Albanian population in Montenegro, we often have restrictions on the exact determination of its number, if the Albanian diaspora is included or not under counted populations by Montenegrin different Censuses. However, the number of Albanians in figures according to Montenegro's official institutions and MONSTAT (Statistical Office of Montenegro) has changed in different periods. According to the statistics, the highest number of Albanian population in Montenegro is presented at the administrative units of Ulcinj, Tuzi, Plava, Rozhaja, Kraja and Gucia. On the statistical data collection, 
we evaluated significant changes has been undergoing, particularly in the second half of the $20^{\text {th }}$ century. The main significant impact has obviously been related to the migratory movements of the Albanian population towards European countries and beyond throughout these years (Axhemi 2002).

Table 2. Number of Albanians in Montenegro according to censuses of population

\begin{tabular}{|c|c|c|}
\hline Period & Noumber of Albanian population & Percentile $\%$ \\
\hline 1921 & 16,838 & 8.45 \\
\hline 1931 & 18,098 & 5.03 \\
\hline 1948 & 19,425 & 5.15 \\
\hline 1953 & 23,460 & 5.58 \\
\hline 1961 & 25,803 & 5.47 \\
\hline 1971 & 35,671 & 6.74 \\
\hline 1981 & 37,735 & 6.46 \\
\hline 1991 & 40,415 & 6.57 \\
\hline 2003 & 31,163 & 5.03 \\
\hline 2011 & 40,439 & 4.91 \\
\hline
\end{tabular}

Source: Wikipedia.

Regarding to the table above, it is evident that there is a systematic decline in the number of Albanian population in Montenegro, converted in the respective percentages in relation to the total population of Montenegro. In the context of a comprehensive analysis of the influencial factors related to the migration movements of the population, which is generally affected by the migration of young males reflected on the structure of age-sex pyramid of population. Later on, the trend is being driven by a decline in the birthrate with real and rapid effects on the natural growth as well as on the number of population and the specific power of this Albanian population in relation to the total number of the population of Montenegro (Draga 1994).

Based on what we mentioned above, our statistics emphasize the fact that many migratory movements of the Albanians of Montenegro have been risen and developed after the 1960s-1970s.

In the reporting of facts, we have been resorted to multiple news sources about the movements of this population, and we have found interesting facts about how the Albanians were not only concentrated primarily on the internal migration toward different cities and countries within the territory of former Yugoslavia, but also focused on external migration toward other European countries and beyond 
(Draga 1994). Referring to the used sources, Italy and Austria have been their primary destination and after that Montenegrin-Albanians attempted to migrate to other countries like France, Switzerland, Germany, Sweden and the USA. These developed nations were also the main destinations where the Albanians of Montenegro were settled.

The Albanians of Montenegro's migration is reported by several sources in MONSTAT. According to the census report of 2003, it is said that $31.45 \%$ of the total Montenegrin population have emigrated (about 52.511 persons). In the meanwhile, Dr. Nail Draga, the Albanian geographer and scholar from Ulcinj has been actice with his potential contribution in the migration analysis of the Albanian population in Montenegro, with numerous studies, scientific papers and publications. The migratory situation in the various Albanian administrative units in Montenegro appears quite interesting, especially after the 1990s and beyond.

Table 3. Albanian population in Montenegro according to Census 2011

\begin{tabular}{|l|c|c|c|}
\hline \multicolumn{1}{|c|}{ Administrative unit } & Number of population & Albanian population & Percentile \% \\
\hline Ulcinj & 19,921 & 14,076 & 70.66 \\
\hline Bar (Tivari) & 42,048 & 2,515 & 5.98 \\
\hline Tuzi & 18,937 & 9,538 & 51.30 \\
\hline Plava & 13,108 & 2,475 & 18.88 \\
\hline Rozhaja & 22,964 & 1,158 & 5.01 \\
\hline
\end{tabular}

Source: MONSTAT (2011).

While many scientific studies have been carried out on the Albanian population in Montenegro by the researcher Nail Draga that provide us some migratory evidence of the Albanian population movement in Malësia e Tuzit and Ana e Malit. Thus, he estimates that at least 200 families have migrated out of Montenegro through Ana e Malit. To this point, the displaced population consists of about one-third of the Albanian population of Ana e Malit in Montenegro. Also, the migratory situation in Malësia e Tuzit should have been taken into account, not only to shed light on the pattern of migration, but the main destinations as well. The most popular destination is the United States, especially Detroit, where the Albanian Community from Tuzi now has traditionally been shaping the contours of a large "family" (Camaj 2013). 


\section{Conclusions}

The cross-border area between Albania and Montenegro is an appealing scientific scope to be explored on the geographical perspective. In the context of a variety of geographical subjects, it is of particular attention to make a comprehensive analysis of features and characteristics of the cross-border population and its social elements. This is shown in two main approaches, both theoretically and practically.

In theoretical terms, it is crucial to specifically develop the scientific opinion on cross-border studies, not only in concepts and geographical visions of the spaces but also on features of population and social topics. These features are particularly marked in the cross-border area of Albania-Montenegro, thus, enriching the theoretical elements related to influential factors in the population development, migratory movements and its socio-economic effects.

In practical terms, it is important to give researchers and other scholars a try to deal with the identification of many important issues related to the number of population in these cross-border areas, such as their position and distribution, structures and influencial factors, population movements and top destinations. This has obviously impacts on perceiving a clear and real image of the crossborder area of Albania-Montenegro, as we have intended to outline this case in our scientific paper.

The development of the cross-border population with Montenegro in Albania identifies some essential features of its evolution in two important periods, one up to the beginning of the 1990 s and the post-1990 transition period. During the first period a 'closed' population could be considered a predominat feature, where the birth-death rates remained always positive in the natural growth context. Whereas, during the transition period a new feature was developed i.e. migratory movements, in particulat external ones (with the main destination to Greece, Italy, and USA).

One more significant feature of this population is the cross-border migration to Montenegro. In particular, we highlight in this respect, the population of the administrative units of Ana e Malit, mainly in Ulcinj and those of the administrative unit of Kastrati in Tuzi. Sporadically, there are also cases of cross-border migration from the administrative unit of Kelmendi towards Plava and Gucia, in recent years. This migratory movement towards Montenegro by the population of these administrative units is mainly influenced by the daily and seasonal employment offers across the border in multiple sectors of the economy. In this regard, we evaluate these sectors such as construction, tourism and other tourism services, 
agriculture, livestock, agriculture, housework services in the families who are away from their home for emigration purpose, etc.

\section{References}

Axhemi S., 2002, A geographical-economic overview of Ulcinj (Një vështrim gjeografikoekonomik mbi Ulqinin), „Scientific Bulletin of the University of Shkodra, Series of Social Sciences", 52, pp. 127-132.

Axhemi S., 2005, Economic, demographic, social aspects of boundary territories at Shkodra's region (Aspektet ekonomike, sociale e demografike të territoreve kufitare të rajonit të Shkodrës), „Geographic Studies”, 15, pp. 103-111.

Camaj A., 2013, General geographical overview of Tuzi Commune, Diploma thesis, Tirana.

Draga N., 1994, Albanians in Montenegro, Ulcinj.

Haxhibrahimi M., 1994, The Ulcinj maritime over centuries, Ulcinj.

MONSTAT (Statistical Office of Montenegro) Census, 2011: https://www.monstat.org/eng /page.php?id=393\&pageid=57 (30.07.2011).

Ushaku R., 1991, Ulcinj on the roots of centuries, Ulcinj.

\section{Dziedzictwo pogranicza i tendencje rozwoju ludnościowego na obszarze przygranicznym między Albanią a Czarnogórą}

Streszczenie

W artykule omówiono wybrane kwestie dotyczące stosunków transgranicznych między Albanią a Czarnogórą, takie jak rozwój populacji i związane z tym problemy społeczne na badanym obszarze w ujęciu przestrzennym. Szczególną uwagę skoncentrowano na zagadnieniu specyfiki ludnościowej miast Szkodra i Malësia e Madhe w części obszaru przygranicznego Albanii oraz miast Kraji, Ulcinj, Plava, Gucia i Tuzi na obszarze przygranicznym Czarnogóry. Wzięto pod uwagę m.in. liczebność ludności w ujęciu dynamicznym, cechy społeczno-kulturowe oraz czynniki, które wpłynęły na ich ewolucję. Wskazano ponadto na tendencje rozwojowe i problemy społeczne z uwzględnieniem kwestii dziedzictwa po obu stronach badanej granicy.

Slowa kluczowe: obszar transgraniczny, rozwój populacji, trendy, dziedzictwo, Albania, Czarnogóra.

Prof. dr. Sokol Axhemi

University of Tirana, Albania

Faculty of History \& Philology

Department of Geography

e-mail: saxhemigraphy@yahoo.co.uk 